\title{
Estimation of alpha-amino nitrogen in plasma and urine by the colorimetric ninhydrin reaction
}

\author{
D. M. MATTHEWS ${ }^{1}$, G. G. MUIR ${ }^{2}$, AND D. N. BARON \\ From the Department of Chemical Pathology, the Royal Free Hospital, London
}

SYNOPSIS Methods are described for the estimation of plasma and urine $a$-amino nitrogen by the colorimetric ninhydrin reaction; in the method for urine, both ammonia and urea are separated. $\vec{v}$ by a rapid ion-exchange resin procedure. Two methods of estimation are given; one has the ad-vantage of great simplicity, but involves the use of cyanide; in the other, cyanide is eliminated. Normal values are reported; they correspond well with those obtained by the gasometric ninhydrin? method.

The estimation of plasma and urine $\alpha$-amino nitrogen, which gives a measure of total aminoacids, is little used in routine chemical pathology. The main reason for this is the lack of a simple and reasonably specific method. The standard ninhydrin$\mathrm{CO}_{2}$ method (Hamilton and Van Slyke, 1943) is gasometric and technically difficult. Folin's colorimatric method for plasma amino-acids (Frame, Russell, and Wilhelmi, 1943), though simple, is non-specific, and the method is unsuitable for urine determinations. The nitrous acid (Peters and Van Slyke, 1932) and formol titration methods (Van Slyke and Kirk, 1933) and the copper method of Albanese and Irby (1944) are all relatively nonspecific, giving considerably higher results than those obtained by the ninhydrin method. The colorimetric ninhydrin method is simple in principle, and probably nearly as specific for $\alpha$-amino nitrogen as the gasometric method, but has not yet come into general use, mainly because of difficulties in the preparation and storage of the ninhydrin reagent, and the fact that it cannot be applied directly to urine because of interference by ammonia and urea. Rubinstein and Pryce (1959) have described a method for the removal of ammonia, but this involves treatment in a desiccator for several hours. The methods given here overcome the main technical difficulties, and enable urinary $\alpha$-amino nitrogen to be estimated without undue delay. Two methods are described, both similar in principle and giving similar results. Method 1 is simpler; however, it

\footnotetext{
'Present address: Department of Chemical Pathology, National Hospital for Nervous Diseases, London, W.C.1.

'Present address: Department of Chemical Pathology, St. Bartholomew's Hospital, London, E.C.1.

Received for publication 9 September 1963.
}

uses cyanide, and many laboratories prefer to avoid $\stackrel{\widehat{?}}{?}$ this. Method 2 avoids cyanide, but the ninhydrinc

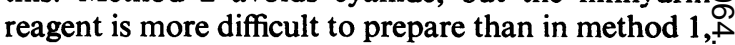
and requires storage under nitrogen. Deionizedo distilled water is used throughout. All reagents are of? A.R. quality when obtainable.

\section{METHOD 1 : ESTIMATIONS IN PLASMA}

The buffer and ninhydrin reasent are modified from Rosen (1957).

REAGENTS The following reagents are required:-

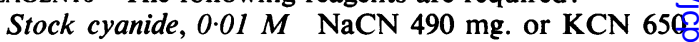
mg. dissolved in 1 litre water.

Cyanide-acetate buffer pH $5 \cdot 2$ To 190 g. $\mathrm{CH}_{3} \cdot \mathrm{COONa}$ $\cdot 3 \mathrm{H}_{2} \mathrm{O}$ add $500 \mathrm{ml}$. water and dissolve. Add $36 \mathrm{ml}$ glacial acetic acid and 5 g. disodium E.D.T.A. Mix well filter if necessary, then add $20 \mathrm{ml}$. of stock cyanide solution and make up to 1 litre with water. Store at $4^{\circ} \mathrm{C}$ ?

Methyl cellosolve (ethylene glycol monomethyl ether Redistilled methyl cellosolve is commercially available (Hopkin \& Williams); alternatively the A.R. reagent cann be redistilled over ferrous sulphate. It should give $a$ negative peroxide reaction with $10 \%$ aqueous $\mathrm{KI}$, and के clear solution on mixing with water. Store at $4^{\circ} \mathrm{C}$.

Ninhydrin reagent Ninhydrin $3 \%(\mathrm{w} / \mathrm{v})$ in methy cellosolve. Store at $4^{\circ} \mathrm{C}$.

Stock standard amino-acid solution Dissolve $536 \mathrm{mg}$ glycine in $100 \mathrm{ml}$. water $\left(\equiv 100 \mathrm{mg}\right.$. $\alpha-\mathrm{NH}_{2} \mathrm{~N}$ per $100 \mathrm{ml}$. 席 Preserve with chloroform and store at $4^{\circ} \mathrm{C}$.

Working standard Dilute $5 \mathrm{ml}$. of stock standard to $100 \mathrm{ml}$. with water on the day of the estimation.

$10 \%(w / v)$ sodium tungstate

$2 / 3 \mathrm{~N} \mathrm{HCl}$ This gives a lower reagent blank tha $\mathrm{H}_{2} \mathrm{SO}_{4}$.

Diluent n-Propanol, or isopropanol, mixed with an equal volume of water. 
PROCEDURE Add $0.2 \mathrm{ml}$. of heparinized plasma to $1.4 \mathrm{ml}$. of water in a centrifuge tube, then add successively, with thorough mixing, $0 \cdot 2 \mathrm{ml}$. of sodium tungstate and $0.2 \mathrm{ml}$. of $\mathrm{HCl}$. Allow to stand for five minutes, and centrifuge. Prepare a standard and a blank by treating $0.2 \mathrm{ml}$. of working standard and $0.2 \mathrm{ml}$. of water, respectively, as plasma. To $1 \mathrm{ml}$. supernatant from test, blank, or standard solution in $150 \times 18 \mathrm{~mm}$. pyrex test tubes add $0.5 \mathrm{ml}$. of buffer and $0.5 \mathrm{ml}$. of ninhydrin reagent. Mix, place metal caps on the tubes and heat in a boiling water bath for 15 minutes. Remove from the bath and immediately add $15 \mathrm{ml}$. of cold diluent (preferably from a $20 \mathrm{ml}$. all-glass syringe). Mix thoroughly by inversion, and read against water at $570 \mathrm{~m} \mu$ in $1 \mathrm{~cm}$. cuvettes (or using an Ilford 404 filter). If the extinction of the test is above 0.75 , either repeat using a smaller quantity of supernatant, or add $2 \mathrm{ml}$. water and a further $15 \mathrm{ml}$. of diluent to test and blank, read again, and double the final answer.

$$
\begin{aligned}
& \text { CALCUlation Plasma } \alpha-\mathrm{NH}_{2} \mathrm{~N}(\mathrm{mg} . / 100 \mathrm{ml} .) \\
& =\frac{(E \text { test })-(E \text { blank })}{(E \text { standard })-(E \text { blank })} \times 5
\end{aligned}
$$

\section{METHOD 1: ESTIMATIONS IN URINE}

The urine is placed on a column of an anion exchange resin in the hydroxyl form. This retains the amino-acids. Urea and ammonia are washed through the column with water. The amino-acids are then eluted with dilute $\mathrm{HCl}$.

REAGENTS These are as follows:-

Ninhydrin reagent, buffer, and stock standard As for plasma

Dowex $2 \times 8,2-400$ mesh

$\mathrm{N}$ and $4 \mathrm{~N} \mathrm{HCl}$

$\mathrm{N}$ and $4 \mathrm{~N} \mathrm{NaOH}$, carbonate-free

Working standard Dilute $0.5 \mathrm{ml}$. of stock standard to $100 \mathrm{ml}$. with water on the day of the estimation.

PREPARATION OF RESIN AND COLUMNS Suspend the resin in water and pour off fine particles. Wash with $4 \mathrm{~N} \mathrm{HCl}$ and allow to stand with shaking for one hour. Repeat until the supernatant is nearly colourless. Wash with water. Wash with $4 \mathrm{~N} \mathrm{NaOH}$ and stand with shaking for one hour. Wash with water, and pour columns. Store excess resin under $4 \mathrm{~N} \mathrm{HCl}$. The resin bed should be 0.9 to $1.0 \mathrm{~cm}$. in diameter and 1.5 to $2 \mathrm{~cm}$. in depth; a bed deeper than this may lead to inadequate elution. Suitable columns may be made by cutting the tips off $10 \mathrm{ml}$. graduated pipettes, inverting them and attaching a rubber tube and screw clip to the mouthpiece, and plugging with glass wool to hold the resin. The resin bed should be renewed after not more than 10 estimations.

PROCEDURE Convert a column to the hydroxyl form by passing through it $20 \mathrm{ml}$. of warm (40 to $\left.45^{\circ}\right) \mathrm{N} \mathrm{NaOH}$. Wash with water until the effluent is neutral. If the urine is alkaline, acidify with a drop of glacial acetic acid. Place $1 \mathrm{ml}$. of urine on the resin and allow to soak in. Wash with $50 \mathrm{ml}$. water; air pressure may be used to accelerate this process. When drained of water, elute with $20 \mathrm{ml}$.
$\mathrm{N} \mathrm{HCl}$, collecting the first $15 \mathrm{ml}$. of eluate. (The resin can then be left under $\mathrm{HCl}$; when required for a fresh analysis, wash with water and again convert to the hydroxyl form.) Add 1 drop of dilute phenolphthalein to the eluate, bring to a faint pink with $4 \mathrm{~N} \mathrm{NaOH}$, and make up to $20 \mathrm{ml}$. with water. Take $1 \mathrm{ml}$. of this, add $0.5 \mathrm{ml}$. of buffer and $0.5 \mathrm{ml}$. of ninhydrin reagent and treat as for plasma supernatant. For the standard use $1 \mathrm{ml}$. of working standard and for the blank $1 \mathrm{ml}$. of water. Neither standard nor blank is put through the resin. Read as above. If the extinction of the test is above $\mathbf{0 . 7 5}$, either repeat using a smaller quantity of urine, or dilute the final solution, as described for plasma.

$$
\begin{aligned}
& \text { Calculation Urine free } \alpha-\mathrm{NH}_{2} \mathrm{~N}(\mathrm{mg} . / 100 \mathrm{ml} \text {.) } \\
& =\frac{(E \text { test })-(E \text { blank })}{(E \text { standard })-(E \text { blank })} \times 10
\end{aligned}
$$

\section{METHOD 2: ESTIMATIONS IN PLASMA}

REAGENTS All reagents and apparatus, unless specially described, are the same as in method 1.

Acetate buffer pH 5.5 Add $272 \mathrm{~g}$. $\mathrm{CH}_{3} \mathrm{COONa} \cdot 3 \mathrm{H}_{2} \mathrm{O}$ to $200 \mathrm{ml}$. water. Mix with warming; when dissolved, cool to room temperature and add $50 \mathrm{ml}$. glacial acetic acid. Make up to $500 \mathrm{ml}$. with water.

Ninhydrin reagent The reagent is a modification by Matheson, Tigane, and Hanes (1961) of that of Moore and Stein (1954). Mix $285 \mathrm{ml}$. of methyl cellosolve, $152.5 \mathrm{ml}$. of water, and $62.5 \mathrm{ml}$. of acetate buffer. Dissolve in this $1.9 \mathrm{~g}$. of ninhydrin. Place in the special container shown in Fig. 1, evacuate for 15 minutes to de-gas the liquid, and replace the air with oxygen-free nitrogen (British Oxygen Co.). Stand at $4^{\circ} \mathrm{C}$. for 12 hours. Add and dissolve $0 \cdot 3 \mathrm{~g}$. of hydrindantin (1,2,3 triketohydrindene, Eastman Chemical Co.), gas thoroughly with nitrogen, and allow the reagent to mature for seven days at $4^{\circ} \mathrm{C}$. It is then stable for at least three months if kept under nitrogen at $4^{\circ} \mathrm{C}$. Before use the 'hydrindantin number' should be determined. Place $2 \mathrm{ml}$. of $8 \mathrm{~N} \mathrm{NaOH}$ in a test tube and flush out with nitrogen, add $4 \mathrm{ml}$. of the reagent, and read the optical density at $570 \mathrm{~m} \mu$ in a $1 \mathrm{~cm}$. cuvette. A satisfactory reagent should give an extinction of 0.2 to 0.8 . The reagent should not be exposed to air for longer than necessary, as this will cause the hydrindantin number to fall.

PROCEDURE Deproteinize plasma and prepare standard and blank as in method 1 . To $0.2 \mathrm{ml}$. supernatant from test, blank, and standard solutions add $2 \mathrm{ml}$. ninhydrin reagent, and place tubes, unstoppered, in a boiling bath for 20 minutes; remove and cool in running water for two minutes. To all tubes add $5 \mathrm{ml}$. diluent, and read as in method 1. If the extinctions of the test solutions exceed $0 \cdot 75$, either repeat using a smaller volume of supernatant, or add $2.2 \mathrm{ml}$. of water and a further $5 \mathrm{ml}$. of diluent, read again and double the final answer.

$$
\begin{aligned}
& \text { CAlculation Plasma } \alpha-\mathrm{NH}_{2} \mathrm{~N}(\mathrm{mg} . / 100 \mathrm{ml} .) \\
& =\frac{(E \text { test })-(E \text { blank })}{(E \text { standard })-(E \text { blank })} \times 5
\end{aligned}
$$




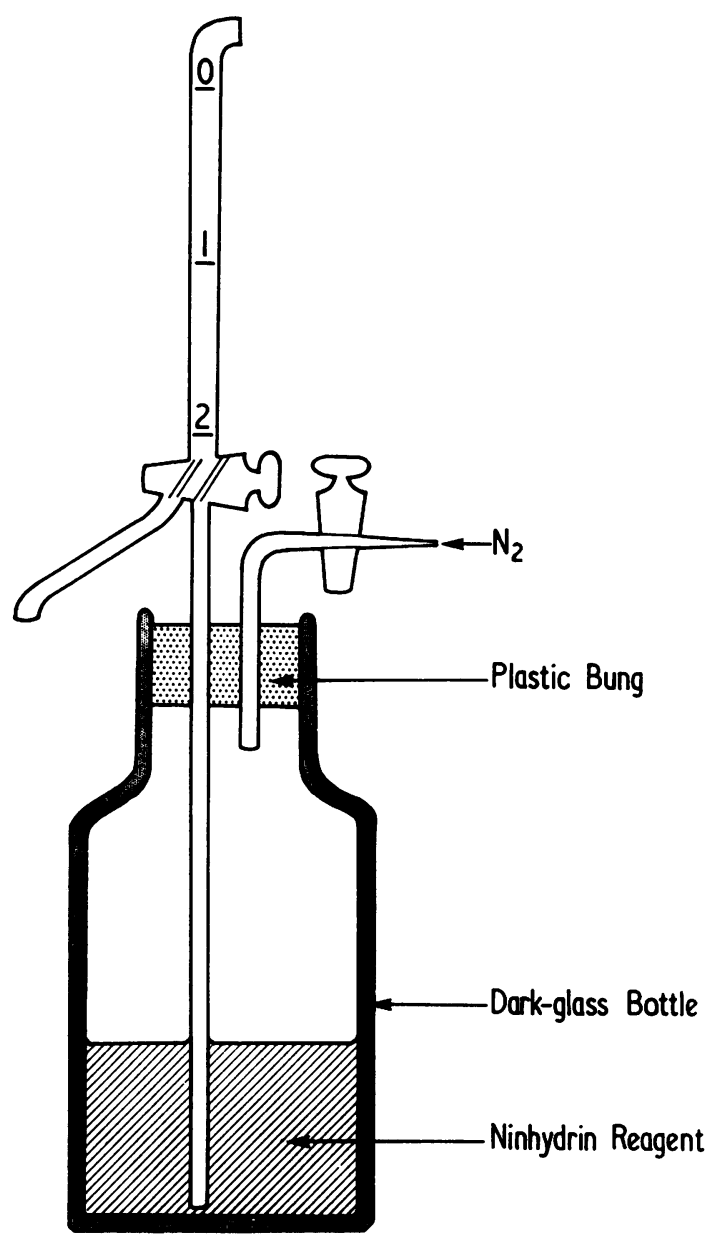

FIG. 1. Container for storage of ninhydrin reagent under nitrogen (method 2).

METHOD 2: ESTIMATIONS IN URINE

PROCEDURE The urine is treated exactly as in method 1. After making up the column eluate to $20 \mathrm{ml}$., take $0.2 \mathrm{ml}$. of this and treat as for plasma supernatant. For the standard use $0.2 \mathrm{ml}$. of working standard for urine prepared as in method 1 , and for the blank $0.2 \mathrm{ml}$. of water. If the extinctions of the test solutions exceed 0.75 , either repeat using a smaller volume of urine, or dilute the final solution as for plasma.

$$
\begin{aligned}
& \text { CALCUlation Urine free } \alpha-\mathrm{NH}_{2} \mathrm{~N} \text { (mg./100 ml.) } \\
& =\frac{(E \text { test })-(E \text { blank })}{(E \text { standard })-(E \text { blank })} \times 10
\end{aligned}
$$

\section{RESULTS AND DISCUSSION}

By both methods a linear standard curve is obtained (Fig. 2). The blue colour produced fades slowly, but is satisfactorily stable for up to one hour. Since ammonia also gives a blue colour with the ninhydrin reagent, it is important to carry out the estimations in an atmosphere free from ammonia vapour.

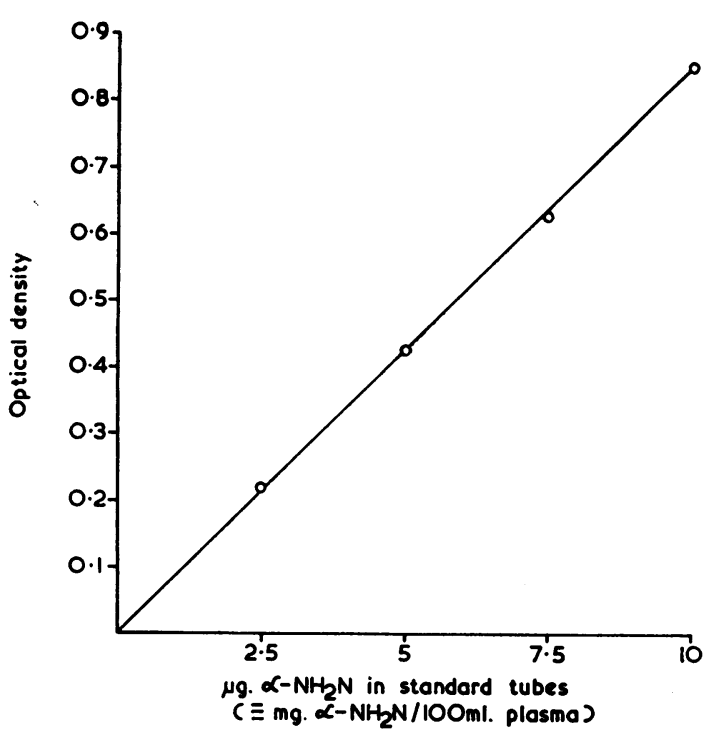

FIG. 2. Standard curve (method 1). Unicam ' 600 ', $570 \mathrm{m \mu} .1 \mathrm{~cm}$. cuvettes.

PLASMA Recoveries of glycine from plasma gave $\overrightarrow{\overline{0}}$ means of $98 \%$, S.D. $3.0, n=4(\operatorname{method} 1)$ and $98 \%$, S.D. $6 \cdot 8, \mathrm{n}=6$ (method 2$)$. Estimations on samples of heparinized plasma taken from normal subjects three hours after breakfast gave values of: Mean? $4.2 \mathrm{mg}$. $\alpha-\mathrm{NH}_{2} \mathrm{~N} / 100 \mathrm{ml}$., S.D. 0.40 , range 3.7 to $5 \cdot 4$, 음 $\mathrm{n}=20(\operatorname{method} 1)$; and mean $4.4 \mathrm{mg} . / 100 \mathrm{ml}$., S.D. $0 \cdot 69$, range $3 \cdot 7$ to $5 \cdot 3, \mathrm{n}=11$ (method 2), these means showing no significant difference. These $₹$ results correspond well with those obtained by the gasometric ninhydrin method (Hamilton and Van $>$ Slyke, 1943; Cramer and Winnick, 1943), and with을 those of Rubinstein and Pryce (1959), who also given further references. Estimations on random samples of serum from normal subjects gave a mean of 0 $5.0 \mathrm{mg}$. $\alpha-\mathrm{NH}_{2} \mathrm{~N} / 100 \mathrm{ml}$., S.D. 0.81 , range 3.5 tow $7 \cdot 0, \mathrm{n}=28$ (method 2$)$. The higher serum values may be partly due to some of the samples not beingo taken in the post-absorptive state, but it is likely that the increase in free amino-acids that is said to ? occur on clotting (Rubinstein and Pryce, 1959; Varley, 1962) also plays a part, and we do not advocate making the estimation on serum.

Urea reacts slightly with the ninhydrin reagents as it does in the gasometric method. Using method 1,0 this interference is proportional to plasma urea 
concentrations up to a concentration of $750 \mathrm{mg}$./ $100 \mathrm{ml}$, and at a urea concentration of $100 \mathrm{mg} . / 100$ $\mathrm{ml}$. corresponds to $0.7 \mathrm{mg} . / 100 \mathrm{ml} . \alpha-\mathrm{NH}_{2} \mathrm{~N}$; using method 2 it corresponds to $0.6 \mathrm{mg}$. $/ 100 \mathrm{ml}$. Consesequently at normal urea concentrations it is equivalent to approximately 0.1 to $0.25 \mathrm{mg}$. $/ 100 \mathrm{ml}$. $\alpha-\mathrm{NH}_{2} \mathrm{~N}$. The normal results given above are not corrected for urea.

URINE The resin will retain neutral and acidic amino-acids and basic amino-acids with the exception of arginine (Jagenburg, 1959). The failure to retain arginine is unlikely to be of importance in routine use. The estimation can be carried out in the presence of proteinuria of up to $1 \mathrm{~g} . / 100 \mathrm{ml}$. without appreciable interference. The mean recovery of glycine from urine by method 1 was $98 \%$ (four experiments) and by method 2, 97\% (three experiments). Urine collections were made from hospital patients with no evidence of renal, hepatic, or endocrine disease. The mean 24-hour output of free $\alpha-\mathrm{NH}_{2} \mathrm{~N}$ was $129 \mathrm{mg}$., S.D. 82, range 47 to 293 , $\mathrm{n}=10$ (method 2). These figures also correspond closely with those obtained by the gasometric ninhydrin method and with those given by Rubinstein and Pryce (1959).

\section{REFERENCES}

Albanese, A. A., and Irby, V. (1944). J. biol. Chem., 153, 583. Cramer, F. B. Jr., and Winnick, T. (1943). Ibid., 150, 259. Frame, E. G., Russell, J. A., and Wilhelmi, A. E. (1943). Ibid., 149. 255.

Hamilton, P. B., and Van Slyke, D. D. (1943). Ibid., 150, 231.

Jagenburg, O. R. (1959). Scand. J. clin. Lab. Invest., 11, suppl. 43, 59. Matheson, A. T., Tigane, E., and Hanes, C. S. (1961). Canad. J. Biochem., 39, 417.

Moore, S., and Stein, W. H. (1954). J. biol. Chem., 211, 907.

Peters, J. P., and Van Slyke, D. D. (1932). Quantitative Clinical Chemistry, vol. 2 (Methods). Williams and Wilkins, Baltimore. Rosen, H. (1957). Arch. Biochem., 67, 10.

Rubinstein, H. M., and Pryce, J. D. (1959). J. clin. Path., 12, 80

Van Slyke, D. D., and Kirk, E. (1933). J. biol. Chem., 102, 651.

Varley, H. (1962). Practical Clinical Biochemistry, 3rd ed. Heinemann, London. 